\title{
The Identification Characteristic about Charismatic Leadership on Islamic Non-Profit Oriented Organization in Indonesia
}

\author{
Dimas Agung Trisliatanto ${ }^{1}$, Suryanto $^{2}$ \\ \{dimas.agung.trisliatanto-2018@ pasca.unair.ac.id ${ }^{1}$, suryanto@psikologi.unair.ac.id ${ }^{2}$ \}
}

\begin{abstract}
Student of Doctoral Program Study of Human Resource Development, Postgraduate School of Universitas Airlangga, Jl. Airlangga No. 4-6, Surabaya - 60285, Indonesia ${ }^{1}$, Faculty of Psychology, Universitas Airlangga, Jl. Airlangga No. 4-6, Surabaya - 60286, Indonesia ${ }^{2}$
\end{abstract}

\begin{abstract}
One of the roles of Ulama' as an Islamic figured that was noteworthy had their position as an educated group that brought enlightenment to the surrounding community. Under the leadership of those who had a great deal of attention to social problems helped the government in raising the level of education and welfare of the people through educational institutions, orphanages and other social activities. The aim was to identifying the characteristics of charismatic leadership on Islamic non-profit oriented organization in Indonesia. The approach used in this study was a conceptual approach and literature study methods. The result was the charismatic leadership trait owned by people who became religious leaders. Kyai and Ulama' had a strong influence in organizing and mobilizing the masses in Islamic non-profit oriented organizations, even members of the organization were willing to accept all things given both knowledge, insight, opinions, problems and even risks.
\end{abstract}

Keywords: Leadership, Charismatic Leadership, Islamic Non-Profit Oriented Organization

\section{Introduction}

Based on Chapter I of General Provisions Article 1 paragraph (1) of Law Number 17 of 2013 concerning Community Organizations, the definition of a community organization Itself is an organization established and formed by the community voluntarily based on common aspirations, wishes, needs, interests, activities, and the purpose of participating in development in order to achieve organizational goals. There are so many types of community organizations in Indonesia, various backgrounds and organizational goals, even the basis of organization such as Islamic non-profit oriented organization.

Islamic non-profit oriented organization is a forum for society to accommodate all thoughts and movements with certain organizational goals that have similarities especially for those who are diverse in Islam [1]. In Indonesia, the existence of Islamic non-profit oriented organization is certainly not separated from organizational goals that lead to patterns of communication and organizational leadership. Leaders are referred to as Kyai and Ulama' have the ability, capacity, and extraordinary charisma in terms of leadership so that the subordinates always obey the orders and instructions. 
Various educational institutions have been born by them both in the form of schools and Islamic boarding schools. All of that is an institution that helped bring the country of Indonesia into an educated nation. They have played a role in advancing science, especially Islam through written works or their missionary channels. At that time, through several Islamic non-profit oriented organization, they also played a role in improving the quality of human resources in Indonesia.

Islamic non-profit oriented organizations, such as: Muhammadiyah, Nahdlatul Ulama', Islamic Unity (Persatuan Islam), Al-Washiyah, the Islamic Tarbiyah Association (Persatuan Tarbiyah Islamiyah), Ansor Youth Movement (Gerakan Pemuda Ansor), the Ansor Multipurpose Lines of Nahdlatul' Ulama (Barisan Ansor Serbaguna Nahdlatul Ulama'), the Pancasila Youth (Pemuda Pancasila), and various other Islamic non-profit oriented organizations must have a leader who is very influential towards his organization. One of the roles of Ulama' as an Islamic figure that is noteworthy is their position as an educated group that brings enlightenment to the surrounding community.

Under the leadership of those who have a great deal of attention to social problems have helped the government in raising the level of education and welfare of the Indonesian people through educational institutions, orphanages and other social activities. There is even a concrete example of the movement of 212 by Muslims as a result of blasphemy by a Governor in one of the Provinces that occurred in 2017, where the action was followed by a number of Islamic non-profit oriented organizations that were driven by Kyai and Ulama'.

Based on this problem researchers want to investigate the identification of characteristics of charismatic leadership in Islamic non-profit oriented organization in Indonesia. The purpose of this study is to identifying the characteristics of charismatic leadership on Islamic non-profit oriented organization in Indonesia. The benefit of this research is to contributing knowledge about the development of human resources in the context of charismatic leadership on Islamic non-profit oriented organization in Indonesia.

\section{Literatures}

\subsection{Organization : Characteristic, Type, and Tipology}

Organizations are often defined as a group of people who work together in order to achieve common goals [2]. Reger in Balliet stated that an organization is a social system that has a regular work pattern and is established by humans and consists of a group of people in order to achieve a particular goal. The definition also confirms that in general the organization has five main characteristics, namely: 1.) Unit/social entity; 2.) A minimum of two members; 3.) Structured work pattern; 4.) Having the goal to be achieved; 5.) Having the identity [4].

Based on the type, broadly the organization could be divided into two types, namely profit oriented organization and non-profit oriented organization [5]. Profit oriented organization is a type of organization that has intentionally established to help people fulfill economic needs, especially the economic needs of the founders or owners of the organization. In the other hand, non-profit oriented organizations make a measure of the success of organizations such as these not profits, but other measures in accordance with the initial objectives of the establishment of the organization. 
Likewise its orientation is not to the owner, but to the constituents It serves. That is, nonprofit oriented organizations are more oriented towards the welfare of constituents than the welfare of its founders. According to Terry in Bulbulia and Frean that organizational typology is grouping types or types of organizations. Grouping of types of organizations can be done using the following criterias: 1.) Based on the quantified leader (the single form and the committee form); 2.) Based on traffic rule (line organization form and line and staff organization) [1].

\subsection{Islamic Non-Profit Oriented Organization}

Non-profit organization is organization that has not related to politics but their role is felt to be no exception in the political world [6]. Islamic non-profit organization is an integral part of the development of Islam, because Islamic non-profit organization has a very important role for the development of Islamic da'wah, especially in Indonesia.

Islamic non-profit organization is one type of non-profit oriented organization with typology where the number of single leaders (Kyai or Ulama') with a straight organizational form that is structured vertically from top to bottom [7]. According to Greenle, Fisher, and Gordon, there are many aspects of the development of Islamic nonprofit organization, among others: theological, culture, personality, social, and organizational [8].

\subsection{Leadership}

Blanchard in Bass and Bass stated that leadership is an activity to influence people to be directed towards achieving organizational goals [9]. Leadership includes the process of influencing in determining organizational goals, motivating follower's behavior to achieve goals, influencing to improve their groups and culture [10]. Leadership is a process, behavior or relationship that causes a group to act together or work together or in accordance with the rules or in accordance with common goals [11].

The leader has the responsibility both physically and spiritually towards the success of work activities from the lead, so that being a leader is not easy and not everyone will have the same in carrying out his leadership [10]. Similarly, the ability and expertise of a leader is a determinant of the success of the development or progress of the institution or organization that he leads.

\subsection{Charismatic Leadership}

Charismatic leader is a leader who embody a motivational atmosphere based on their commitment and emotional identity to their vision, philosophy and style in their subordinates [12]. Therefore charismatic leadership can be interpreted as the ability to use privileges or excess personality traits in influencing the thoughts, feelings and behavior of others, so that in an inner atmosphere admiring and glorifying leaders is willing to do something desired by the leader.

The impact of a charismatic leadership is lead to believing the leader has right, accepting the leader without questioning It, submitting to the leader with pleasure, feeling affection for the leader [13]. In general, a leader must be able to convince its members, and they can trust all the policies that will be issued by the leader. So the leader can be a role model to motivate their subordinates to work positively more than usual. 


\section{Method}

The approach used in this study is a conceptual approach to literature study methods. This literature study uses various references in the form of journals, previous research, and documents as related data sources [14].

\section{Results and Discussion}

The success of the Kyai and Ulama' are determined by his charisma generally. This is charisma could determine the progress and retreat of the organization that he leads. Charisma of Kyai and Ulama' growth out of their knowledge and personality as well as teaching structures based on the transmission of knowledge from one generation to another by using an individual guidance system with a diploma system traditionally. The diploma system is the blessing, permission and trust of a Kyai or Ulama' who is given to his students to teach a book to a particular branch of science in the religious sciences who he has taught.

This system caused the students to rely on their Kyai or Ulama' intellectually and make them to become a lifelong guide. Charismatic aspects are an important key to the continuity of the leadership of the Kyai and Ulama'. Besides, sometimes this model has a negative impact if there is a leadership succession. In this relationship, Porter said that the loss of a charismatic figure in certain cases can lead to changes in the source of charisma, namely the charisma that is based on person who have the charisma of services from previous people (charisma of office) or hereditary charisma [2].

In the process, there are important aspects that Weber in Epley stated the preservation of charism routinization of charisma [1]. The loss of charisma with the existence of a new form of authority is accompanied by the emergence of new institutions so that there is a time when social change is born [15]. The role of Kyai and Ulama' in a government both at the central and regional levels is very large, It is not only as figures and role models because their behavior but also a leader figure that is considered ideal by the community [16].

Infrequently, the existence of Kyai and 'Ulama in the practical political space and Indonesian bureaucracy seemed never to be discussed in full by sharing rumors, issues, intrigues, interests and controversies. Sometimes, even the intervention of Kyai and 'Ulama in politics have been considered as an infidelity function where Kyai and 'Ulama are positioned as a person who pawns God's verses for mere political gainly.

Whereas if examined further, the involvement of Kyai and 'Ulama in the contemporary Indonesian bureaucratic politics, are actually only the outermost cover of a long and tiring historical role and not merely a manifestation of momentary individual ambitions. The existence of Kyai and 'Ulama in the area of practical politics are basically inseparable from the pro and contra of obsolescence about the need for unification or the importance of the separation between religion and the state [17].

Kyai and 'Ulama are thinking that the Islamic boarding school is considered a small kingdom where Kyai and 'Ulama are an absolute source of power and authority (Power of authority) within the Islamic boarding school generally. No one can reject the decision of the Kyai and 'Ulama in a pesantren. In the other hand, students believe that the Kyai and 'Ulama they follow are people who have full confidence in themselves highly both in matters of Islamic religion and in the field of power and management in Islamic boarding school. 
Generally, It stated that Kyai and 'Ulama still have high influence on people's lives. The influence of charismatic leadership seems not only to the general public but also to the political party officials or figures [18]. Empirically, the reality of Kyai and 'Ulama are contested by people who will hold certain political positions.

\section{Conclusion}

This charismatic leadership trait is owned by people who become religious leaders. A person's appearance is considered charismatic. It could be seen from his physical characteristics, such as his glowing eyes, his strong voice, his prominent chin or other signs. Charismatic leadership which is owned by Kyai and Ulama' have a strong influence in organizing and mobilizing the masses in Islamic non-profit oriented organizations, even members of the organization are willing to accept all things given both knowledge, insight, opinions, problems and even risks. This was obtained from the suitability of various references and previous studies both supporting and comparing.

Acknowledgments. The researcher expressed his gratitude to the Lecturer of the Communication and Leadership course at the Doctoral Study Program of Human Resource Development in Postgraduate School of Universitas Airlangga and the assistance of Kyai and Ulama' who have provided excellent guidance and direction so that this journal can be resolved.

\section{References}

[1] Epley, J. L.: Weber's Theory of charismatic leadership: The case of muslim leaders in contemporary Indonesia politics. Vol. 5 (7), pp. 7-17. International Journal of Humanities and Social Science (2015)

[2] Porter, D. J.: Managing politics and Islam in Indonesia (Ed. Rev.). RoutledgeCurzon, London (2012)

[3] Balliet, D.: Communication and cooperation in social dilemmas: A meta-analytic review. Vol. 54, pp. 39-57. Journal of Conflict Resolution (2010)

[4] Morris, A. \& Staggenborg, S.: Leadership in social movements. In D.A. Snow, S.A (2007)

[5] Olivola, C. Y. Funk, F., \& Todorov, A.: Social attributions from faces bias human choices. Vol. 18 (11), pp. 566-570. Trends in Cognitive Sciences (2014)

[6] Kamaruddin, M. I. H. \& Ramli, N. M.: A case study of internal control practices in Islamic non-profit organization in Malaysia. Vol. 8, pp. 13-25. Asian Journal of Accounting and Governance (2015)

[7] Jabnoun, N.: Islam and management. international Islamic publishing house, Saudi Arabia, Riyadh (2012)

Joosse, P.: Silence, charisma and power: The case of John de Ruiter. Vol. 21, pp. 355-371. Journal of Contemporary Religion (2006)

[8] Greenlee, J., Fisher, M. \& Gordon, T.: An investigation of fraud in non-profit organizations: Occurrences and deterrents. Vol. 36 (4), pp. 676-694. Nonprofit and Voluntary Sector Quarterly (2007) 
[9] Bass, B. M. \& Bass, R.. The Bass handbook of leadership: Theory, research, and managerial application. The Free Press, New York (2009)

[10] Antonakis, J., Bastardoz, N., Jacquart, P., \& Shamir, B.: Charisma: An Ill-defined and ill-measured gift. Vol. 3 (1), pp. 55-65. Annual Review of Organizational Psychology and Organizational Behavior (2016)

[11] Sarwono, S. W.: Social Psychology: Grouping and Application. Balai Pustaka, Jakarta (2005)

[12] Takala, T.: Charismatic leadership and power. Vol. 3, pp. 45-57. Problem and Perspective in Management (2005)

[13] Joosse, P.: Becoming a God: Max Weber and the social construction of charisma. Vol. 14, pp. 30-42. Journal of Classical Sociology (2014)

[14] Denney, A. S. \& Tewksbury, R.: How to write a literature review. Vol. 24 (2), pp. 218 234. Journal of Criminal Justice Education (2013)

[15] Ingram, H. J.: The charismatic leadership phenomenon in radical and militant Islamism. Ashgate, Surrey (2013).

[16] Bulbulia, J., \& Frean, M.: The evolution of charismatic cultures. Vol. 22, pp. 254-271. Method and Theory in the Study of Religion (2010)

[17] Hofmann, D. C.: Warriors and Prophets: The role of charismatic authority in the radicalization towards violence and strategic operation of terrorist groups. A Presented Dissertation. Doctor of Philosophy in Sociology and Legal Studies. University of Waterloo (2015)

[18] Fragouli, E.: The dark side of charisma and charismatic leadership. Vol. 9 (4), pp. 298307. The Business and Management Review (2018) 